\title{
Using Ecosan sludge for crop production
}

\author{
B. Jimenez ${ }^{\star}$, A. Austin**, E. Cloete ${ }^{\star \star *}$ and C. Phasha*** \\ *Engineering Institute, UNAM Apdo. Postal 70472; 04510 Coyoacan, Mexico D. F. \\ (E-mail: bjimenezc@iingen.unam.mx) \\ ${ }^{* \star C S I R ~ B u i l d i n g ~ a n d ~ C o n s t r u c t i o n ~ T e c h n o l o g y, ~ P r e t o r i a, ~ S o u t h ~ A f r i c a ~}$ \\ ***University of Pretoria, Department of Microbiology and Plant Pathology, University of Pretoria, \\ 0001 Pretoria, South Africa
}

\begin{abstract}
This paper presents the microbial risks associated with the reuse of Ecosan sludge in agriculture. Sludge from KwaZulu Natal Province in South Africa with a helminth ova content of $30 \mathrm{HO} / \mathrm{g} \mathrm{TS}$, faecal coliforms of $10^{6} \mathrm{CFU} / \mathrm{g}$ TS, faecal streptococci of $10^{6} \mathrm{CFU} / \mathrm{g}$ TS and Salmonella spp. of $10^{5} \mathrm{CFU} / \mathrm{g}$ TS was used for this purpose. Applying different rates of sludge to spinach and carrots resulted in an increase in bacterial and helminth ova counts in crops as the quantity of sludge increased. The helminth ova content in crops was always greater in leaves than in stems, with a content varying from 2 to $15 \mathrm{HO} / \mathrm{g}$ TS for spinach with sludge application rates of $0-37.5 \mathrm{ton} / \mathrm{ha}$ and from $2-8 \mathrm{HO} / \mathrm{g}$ TS for carrot crops with sludge application rates varying from 0-35 ton/ha. Nevertheless, viability in crops was 20-25\%, reducing the risk of disease. Consequently, the development of an Ecosan sludge revalorisation standard is considered important. Some recommendations are made taking into account the characteristics of the sludge as well as conditions in rural areas.
\end{abstract}

Keywords Agriculture; bacterial indicator organisms; Ecosan; health risks; helminth ova; reuse; sludge

\section{Introduction}

Ecosan is a special class of sludge with little known characteristics because it is produced in systems based on a recently developed on-site sanitation concept. The composition of Ecosan sludge differs substantially from latrine sludge and sludge from conventional sewage treatment processes because it is produced in toilets where faeces are separated from urine and kept in dry conditions and not mixed with other liquid wastes. This lack of humidity inactivates the microorganisms contained in faeces by transforming them into a dry material that is easy to handle (Schonning, 2001), but still needs to be disposed of carefully to minimise the risk of disease. As part of the Ecosan concept, sludge revalorisation in agriculture, as a zero-cost fertiliser, is promoted to increase crop production in rural areas, as well as to close the ecological cycles of nutrients and organic matter (Esrey et al., 1998). To face the challenge posed by the 2.6 billion people in the world with no sanitation, Ecosan toilets are being widely promoted and installed, generating sludge that needs to be managed. Furthermore, the potential use of the sludge in domestic vegetable gardens for improving the livelihood of the rural poor needs to be assessed, along with social acceptability and communication campaigns which are beyond the scope of this paper.

As sewage sludge, Ecosan sludge is a valuable soil conditioner because it contains organic matter, nitrogen and phosphorus. Unfortunately, it also represents a health risk due to its pathogen content. Little is known about Ecosan sludge disposal. Furthermore, its disposal is not regulated by legislation, which usually only contains criteria for sludge produced in centralised sewer systems or in latrines (septage). As a consequence, Ecosan sludge is often considered as septage for disposal purposes, therefore limiting its use in 
agriculture. At the present time, several developing countries are facing the challenge of developing scientifically based, but feasible and useful standards within their social and economical context to manage sludge. One aspect to deal with is the selection of affordable and realistic maximum permissible pathogen levels for several types of sludge containing very high initial pathogenic content that make sludge difficult to treat (Jimenez and Wang, 2006; Jimenez et al., 2004). In the case of on-site sanitation systems, the challenge is even greater because health risks are normally higher in the areas where this type of sanitation is most appropriate and regulations are more difficult to implement. However, to protect health by using Ecosan sludge as a fertiliser, it is important to apply risk assessment methodologies using the pollutant contents in crops as data. In this context, the objective of this research was to: (a) characterise Ecosan sludge and evaluate its microbial effects on crops; (b) establish recommendations regarding regulations; and (c) provide reliable information to support scientists involved in the development of on-theground domestic crop fertilising strategies.

\section{Methods}

Sludge from different Ecosan toilets from KwaZulu-Natal Province in South Africa mixed with topsoil and stored for 12 months was characterised and applied to spinach and carrots. These crops were selected because they are commonly consumed in South African rural areas, may be consumed raw and, for spinach, the edible parts grow above the soil, while the carrots grow below the ground. Experiments were carried out in plots $(2 \times 9 \mathrm{~m})$ at the experimental farm of the Pretoria University. Seeds were sown in November, 2005 (summer time). The pattern within the blocks was in rows $300 \mathrm{~mm}$ apart. The seeds were spaced $50 \mathrm{~mm}$ apart within the rows. Each crop was planted in two plots; one was used as a control while the other was divided into three sections each receiving different sludge application rates. Sludge was applied to soil and mixed to a depth of $10 \mathrm{~cm}$. The sludge rate was chosen considering: (a) the nitrogen demand $(50 \mathrm{~kg} \mathrm{~N} / \mathrm{ha}$ for carrots and $100 \mathrm{~kg}$ $\mathrm{N} /$ ha for spinach) of crops; (b) an application rate above and below 8 ton/ha, which is the value established in the South African standards; and (c) three different helminth ova rates (quantity of helminth ova applied, measured as total or viable, per square centimetre). To enable the crops to grow at the same rate, the total quantity of $\mathrm{N} / \mathrm{ha}$ in plots was kept constant by adding a commercial fertiliser (LAN with $28 \% \mathrm{~N}$ content). Sludge and helminth rates used in this study (Table 1) need to be compared with the one of 0.016 viable $\mathrm{HO} / \mathrm{m}^{2}$ for sludge having 1 viable helminth ovum/g TS applied at a rate of $8 \mathrm{ton} / \mathrm{ha}$, as established in South African regulations, as well as with application rates of $0.4 \mathrm{HO} / \mathrm{cm}^{2}$ for carrots and $0.8 \mathrm{HO} / \mathrm{cm}^{2}$ for spinach obtained using US EPA regulation to fulfil the nitrogen demand by crops with sludge containing 0.25 viable helminth ova/g TS. Spinach was harvested in January ( 7 weeks) and carrots in March (12 weeks). Analyses were performed in sludge in soil before sowing and after harvesting, and in crops once

Table 1 Sludge and helminth ova application rates in spinach and carrots

\begin{tabular}{|c|c|c|c|c|c|c|}
\hline \multirow[t]{3}{*}{ Experiment } & \multicolumn{3}{|c|}{ Spinach } & \multicolumn{3}{|c|}{ Carrots } \\
\hline & \multirow{2}{*}{$\begin{array}{l}\text { Sludge } \\
\text { Ton/ha }\end{array}$} & \multicolumn{2}{|c|}{ Helminth ova, $\mathrm{HO} / \mathrm{cm}^{2}$} & \multirow{2}{*}{$\begin{array}{l}\text { Sludge } \\
\text { Ton/ha }\end{array}$} & \multicolumn{2}{|c|}{ Helminth ova, $\mathrm{HO} / \mathrm{cm}^{2}$} \\
\hline & & Total & Viable & & Total & Viable \\
\hline Control & 0 & 0 & 0 & 0 & 0 & 0 \\
\hline 1 & 1.3 & 0.18 & 0.16 & 7 & 1.0 & 0.9 \\
\hline 2 & 19 & 2.6 & 2.3 & 12.5 & 1.7 & 1.5 \\
\hline 3 & 37.5 & 5.1 & 4.5 & 35 & 4.8 & 4.3 \\
\hline
\end{tabular}


harvested. The serial dilution technique (Islam et al., 2005) was used to measure the total coliforms, faecal streptococci and faecal coliforms. For Salmonella spp., the same technique was used initially, but was changed to a standardised technique (9260 from APHA, AWWA, WEF (1995)) during the course of the experiment. Nitrogen, total solids, and $\mathrm{pH}$ were monitored using APHA, AWWA, WEF (1995) procedures. For helminth ova content, the procedure suggested by the US EPA (1992) was used.

\section{Results and discussion}

Ecosan sludge had a TS content of $43 \pm 2 \%$, which is higher than the value commonly found in septage or in sludge from conventional wastewater treatment plants (4\% for secondary biological thickened sludge to $28 \%$ for filter pressed sludge using chemicals, according to Metcalf and Eddy, 2003). The moisture content (57\%) was low, but not enough to completely inactivate microorganisms (below $30-40 \%$ in general and $<5 \%$ for Ascaris eggs, according to Feachem et al., 1983). The N content $(0.2-0.34 \%)$ was in the normal range for domestic sludge $(0.2-0.6 \%)$ if the $\mathrm{N}$ contribution due to urea is subtracted (90\% of the value according to Metcalf and Eddy, 2003).

Concerning the microbial content, faecal streptoccoci $\left(10^{6} \mathrm{CFU} / \mathrm{g} \mathrm{TS}\right)$, faecal coliforms $\left(10^{6} \mathrm{CFU} / \mathrm{g}\right.$ TS $)$ and Salmonella $\left(10^{5} \mathrm{CFU} / \mathrm{g}\right.$ TS $)$ were within the range for similar types of sludge, but also in agreement with sludge from conventional wastewater treatment systems (Table 2). The relatively high bacterial content compared to helminth ova seems to be common in Ecosan sludge. Moe and Izurieta (2003), cited in Strauss et al. (2003), indicated that faecal coliforms may survive $>1,000 \mathrm{~d}$ in Ecosan sludge, while Ascaris may be completely inactivated. The helminth ova content $(29.8 \pm 2.9 \mathrm{eggs} / \mathrm{g}$ TS $)$ was less than expected for sludge from developing countries (ranging from 67 to $3,000 \mathrm{ova} / \mathrm{g}$ TS) and is comparable to results obtained in anaerobic digested sludge in South Africa (2-40 Ascaris/g TS; Chale-Matsau, 2005). This sludge is classified as "Type B" in South Africa and can be reused for agriculture with some restrictions to minimise human exposure.

The helminth ova content in faecal sludge reported in literature (from latrines or Ecosan) varies broadly. Although literature is clear on the conditions required to inactivate Ascaris eggs $\left(>40{ }^{\circ} \mathrm{C}\right.$, moisture $<5 \%$, according to Feachem et al. (1983) and $\mathrm{pH}>12$, according to US EPA (1992)), field observations from faecal sludge are less conclusive (Strauss et al., 2003) due to the different combinations of the operating conditions used for Ecosans (initial helminth ova content, storage time, temperature, and $\mathrm{pH}$ ), different units used to report (eggs/L, Ascaris/g TS, helminth eggs/g TS) and also to different analytical techniques used to determine the helminth ova content (Jimenez et al., 2006). These factors led to the conclusion that regarding Ecosan it would be inappropriate to generalise conditions to ensure pathogen die-off (Strauss and Blumenthal, 1990; Austin, 2001). This conclusion makes government reluctant to widely recommend Ecosan sludge revalorisation for domestic food production purposes.

Helminth ova composition in sludge differs from one region to another reflecting health conditions. In this study, $85 \%$ of the eggs $(25.3 \pm 4.4 \mathrm{ova} / \mathrm{g}$ TS) were Ascaris eggs (Figure 1). The Taenia eggs' presence was variable with values up to $19 \%$, a value higher than reported by other authors (Cabaret et al., 2002; Jimenez et al., 2002). Taenia is linked with oncocercosis cysts in meat. Cysticercosis, due to Taenia saginata (common in Africa), appears to be one of the major pathological threats when sewage sludge is used to fertilise cattle pastures in temperate areas (Cabaret et al., 2002). Therefore they deserve special attention, and it may be necessary in South Africa to establish the maximum content in sludge, not only for Ascaris eggs but also for all helminth eggs. Unlike previous 
Table 2 Ecosan sludge biological characterisation and comparison with other studies

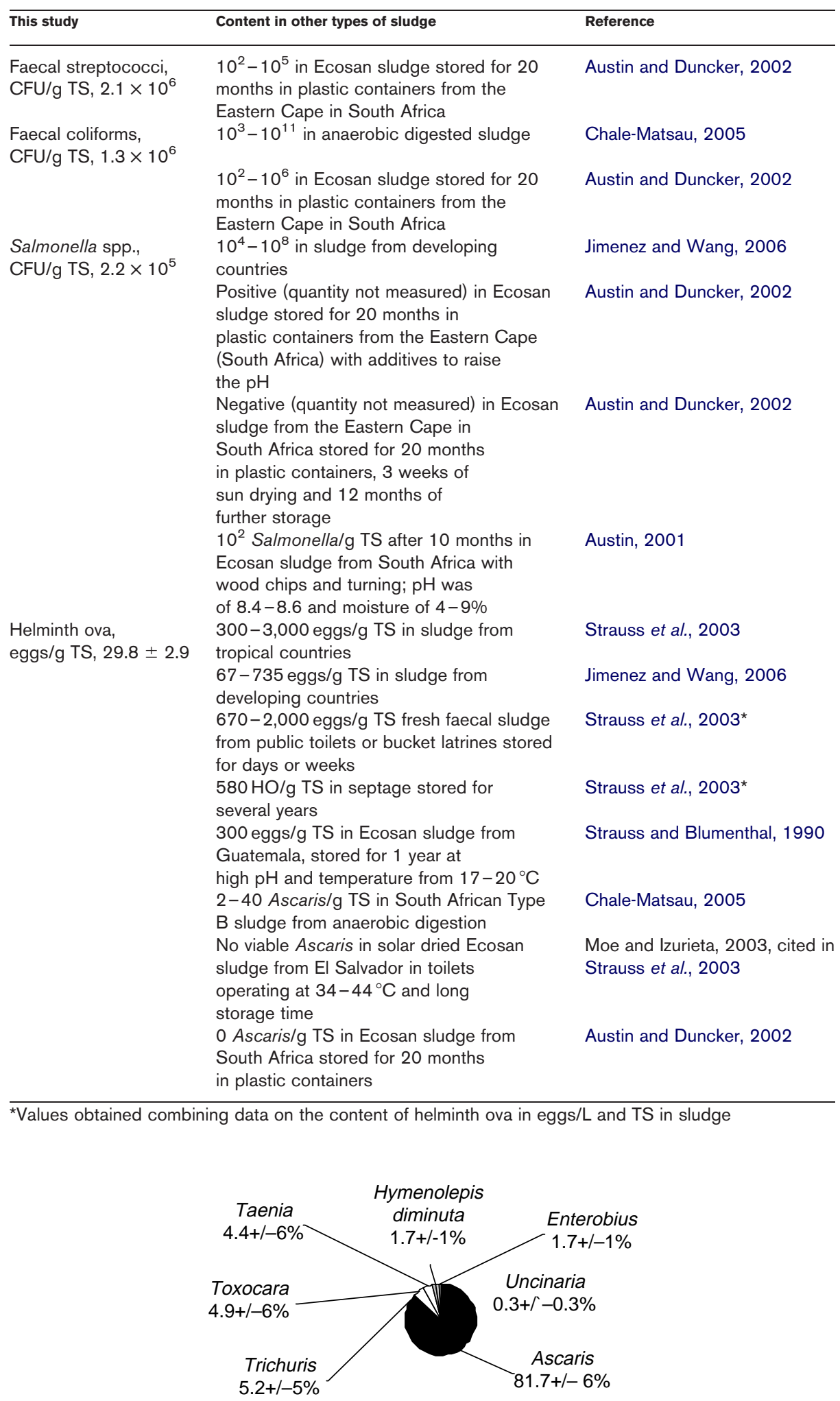


research, it was observed that $65 \%$ of the Ascaris and Trichuris eggs were larval indicating that for some reason, the operating conditions in Ecosan promote development of eggs.

\section{Irrigation water}

Water used for irrigation was pumped from a nearby borehole and stored in open tanks, without disinfection. Birds were often drinking from tanks, which could explain why microbial pollution was found, albeit in low concentrations. Faecal coliforms ranged from $0.2-0.9 \mathrm{CFU} / 100 \mathrm{~mL}$ and faecal streptococci from $0-0.1 \mathrm{CFU} / 100 \mathrm{~mL}$. Salmonella spp. and helminth ova were not detected.

Soil

Soil was slightly alkaline ( $\mathrm{pH} 7.7)$ throughout the experiment, and contained total and faecal coliforms (Table 3). Total coliforms are native in soil, while faecal coliforms have been reported as native in water of high-temperature countries (Hazen and Toranzos, 1990). Faecal streptococci and Salmonella (using the APHA, AWWA, WEF, 1995 method) were not found, while helminth ova were present in low numbers $(1.4 \pm 0.5 \mathrm{HO} / \mathrm{g} \mathrm{TS})$ and very low viability $(0-10 \%)$. According to the farm records, the plots had not received manure application (where helminth ova may be present) for at least 1.5 years. Almost all eggs found were Ascaris, although Toxocara eggs were sometimes reported.

After harvesting carrots, the faecal bacteria (Figure 2a) and helminth ova (Figure 2b) content was greater in plots that received a greater amount of sludge. Salmonella was not detected for any application rate. For spinach soil, similar results were found. The survival of faecal bacteria in soil was reported by Kudva et al. (1998) for up to 1 year while Salmonella spp. has been registered for 10 weeks following land application (Jones, 1980). Helminth ova viability decreased considerably in soil (from 88.8 to $52 \%$ for spinach and to $39 \%$ for carrots). The higher decrease in carrot experiments may be attributed to the longer amount of time that helminth ova remained in the soil (12 weeks vs. 7 weeks). The reason why viability is diminished is not clear, as crops were irrigated every day. One possible explanation, although not conclusive, may be the high temperatures registered during the summer time in Pretoria (ranging from $27-38{ }^{\circ} \mathrm{C}$ during the day) combined with a lower persistence of larval eggs. Ascaris eggs have been reported to rapidly die at temperatures over $40^{\circ} \mathrm{C}$ in water, soil, sewage, and crops (Feachem et al., 1983), a limit that could be less, if high temperatures are combined with other environmental conditions such as low moisture (Heinonen-Tanski and Van Wijk-Sijbesma, 2004).

\section{Crops results}

For spinach, in general, there is no clear relation between the quantity of sludge applied and the microbial content in leaves and stems. For faecal coliforms in stems (Figure 3a

Table 3 Initial soil characteristics

\begin{tabular}{ll}
\hline Parameter & Value \\
\hline $\mathrm{pH}$ & $7.7 \pm 0.21$ \\
TS content (Moisture) & $86 \pm 2(14 \% \pm 2)$ \\
Total coliforms & $8.1 \times 10^{3}-2.7 \times 10^{5}$ \\
Faecal streptococci & 0, absent \\
Faecal coliforms & $2.6 \times 10^{3}-1.1 \times 10^{4}$ \\
Salmonella & 0, absent \\
Total helminth ova/g TS & $1.4 \pm 0.5$ \\
Viability & $0-10 \%$ \\
\hline
\end{tabular}



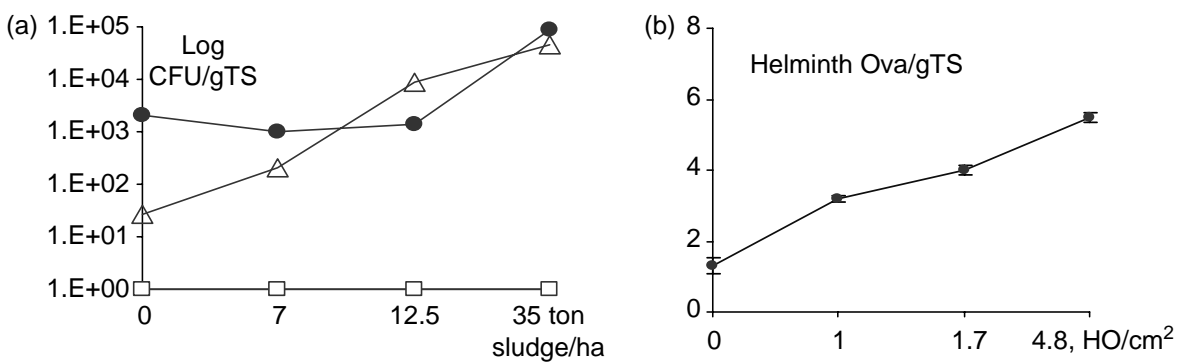

Figure 2 (a) Bacterial content in carrot soil. $\Delta$ Faecal streptococci; $\bullet$ Faecal coliforms; $\square$ Salmonella. (b) Helminth ova content in carrot soil

and b) the results seem to indicate that these bacteria survived underground, but not above the soil, where UV sunlight is available, and may contribute to the decrease in bacterial numbers. In carrots, faecal coliforms and faecal streptococci numbers increased, in both leaves and carrots, as the sludge application rate was increased (Figure $3 \mathrm{c}$ and d). Salmonella spp. was not found in crops for any sludge application rate. Concerning helminth ova (Figure 4), the content increased with the sludge application rate, and, in general, concentrations were greater in leaves than in stems indicating that helminth ova attach preferentially to plants rather than to soils. Unfortunately, for spinach, helminth ova viability was not measured. Helminth ova viability in carrots was $25 \pm 5 \%$ in leaves and $20 \pm 8 \%$ in carrots, thus although helminth ova were present in crops their low viability reduced the health risk. Therefore, the actual effect on health by reusing Ecosan sludge for agriculture needs to be established through a proper risk assessment that considers the real infectivity of eggs for farmers and consumers.

\section{Behaviour of helminth ova per genus}

Ascaris eggs are commonly considered as one of the most persistent organisms in the environment, and therefore regarded as an indicator of hygienic quality (WHO, 1989; Strauss et al., 2003). Also, very frequently, Ascaris eggs are common in wastewater and

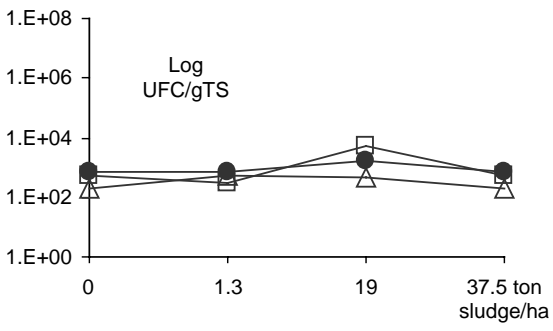

(a) Spinach leaves

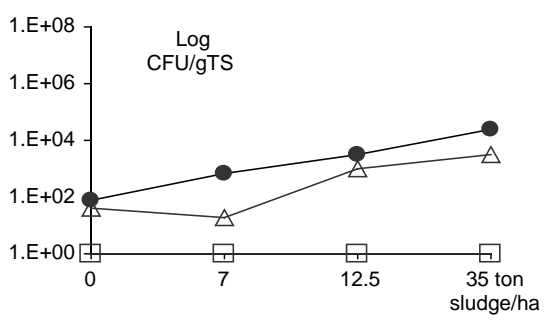

(c) Carrot leaves

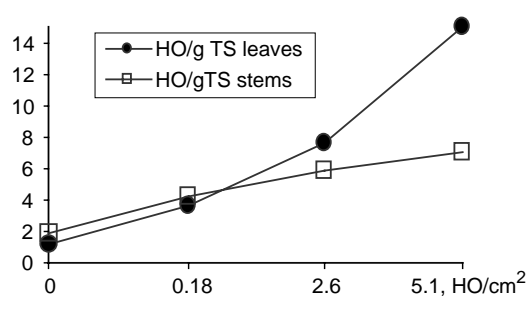

(b) Spinach stems

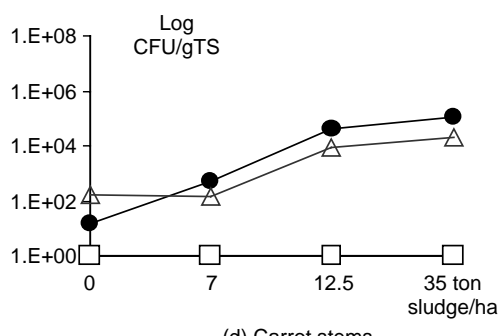

(d) Carrot stems

Faecal coliforms; $\square$ Salmonella 


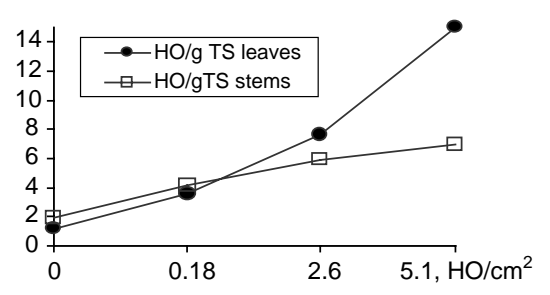

(a) Spinach

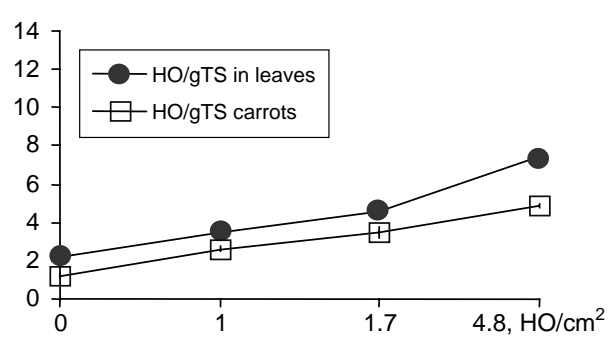

(b) Carrots

Figure 4 Helminth ova content in crops

sludge (Cabaret et al., 2001, and Jiménez et al., 2002). For this reason, in regulations and very often in research studies, Ascaris is the only helminth considered. Figure 5 shows the number of genera detected in carrots for different sludge application rates. It is evident that the probability of finding other genera than Ascaris is related more to the initial total content of helminth ova in soil rather than the persistence of different eggs. Figure 6 shows that the helminth ova genus distribution in crops tended to be similar to that of sludge.

\section{Recommendations for Ecosan sludge regulations}

Ecosan is a useful technology for rural areas, producing sludge with better quality than latrines. For these reasons, Ecosan toilets are being installed around the world and the reuse of the sludge for agriculture is often recommended. Therefore, there is a need to consider Ecosan sludge in regulations, but taking into account their characteristics as well as the rural conditions where Ecosan toilets are installed, especially in developing countries. A first consideration is to establish limits, not only for Ascaris eggs, but also for all helminth eggs to cover all different local health conditions. This is true not only for Ecosan sludge but for any kind of sludge. Regarding Ecosan sludge, viability seems to be an important parameter, related to the actual infective capacity of helminth eggs. This parameter should be used to determine the actual health risk on farmers and crop consumers. Currently, there is only one recommendation from Xanthoulis and Strauss (1991), of 3-8 viable nematode eggs/g TS obtained by extrapolating the criteria provided by WHO for water reuse in agriculture. Another issue to consider in rural areas is the low capacity for monitoring sludge. Thus, standards may only be based on Ecosan operating conditions rather than on pathogen values. However, for establishing proper operating

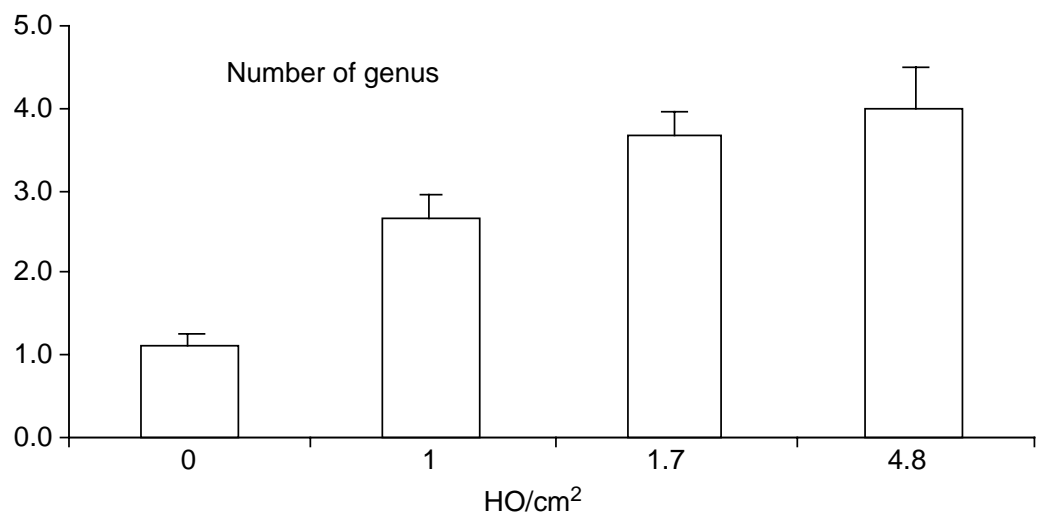

Figure 5 Genus detected in soil 


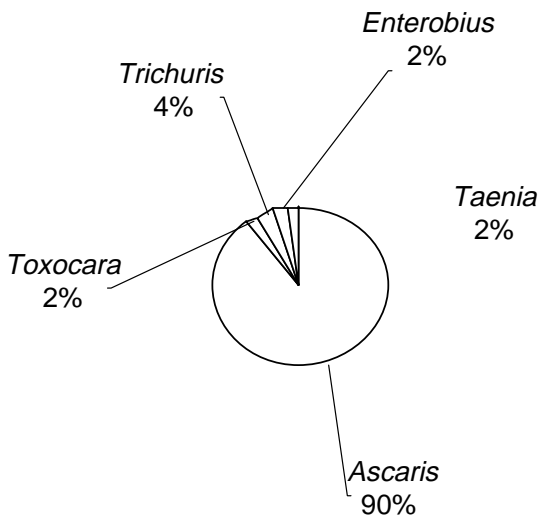

Figure 6 Helminth ova distribution in crops

conditions, the target value in the treated sludge is once again needed. With this value and through field studies to establish how the sludge storage time, moisture and $\mathrm{pH}$ act on pathogens dying off in an isolated and combined way, the operating conditions may be defined. At the present time, conditions are established very broadly, not consistently and using large and different safety factors. Moreover, considering that the most critical pollutant in sludge (any type) from developing countries is the pathogen content, it may be worth considering it for sludge revalorisation in agriculture to establish a maximum sludge application rate based on the pathogen content rather than based only on parameters like metals or nitrogen content.

\section{Conclusions}

The Ecosan sludge from the Kwazulu Natal region has a microbial content similar to South African anaerobically digested sludge, a sludge classified as "Type B" and that may be used for agriculture with some restrictions. Applying different rates of Ecosan sludge to spinach and carrots, it was found that the bacterial and helminth ova contents in crops were greater as the quantity of sludge increased. Helminth ova content in crops was always greater in leaves than in stems, indicating that eggs attach preferably to plants rather than to soil. Viable helminth ova in carrots were $20-25 \%$, thus reducing the risk of diseases spreading; the reason why viability is so low is not yet clear. Considering the expansion of Ecosan, there is a need to establish a specific regulation, rather than view them and regulate them as septage. For this purpose, Ecosan sludge characteristics, as well as rural conditions, must be taken into account. Finally, considering the variable helminth ova data on Ecosan sludge reported in literature, it is recommended: (a) that standardised conditions be defined for for reporting results (for instance, ova/g TS rather than ova/L or ova/g wet matter); (b) to always measure egg viability; (c) to report the analytical methods used for helminth ova detection; and (d) to perform research work in controlled conditions to assess the influence of operating conditions on the viability of eggs. Considering the potential of Ecosan sludge for improving rural livelihoods, social scientists should be involved early in assessing social acceptability and devising adequate communication measures. Concerning the use of Ecosan sludge as fertiliser based on the results found, it is recommended to restrict it to crops with no contact with soils and/or crops that are consumed cooked. 


\section{Acknowledgements}

This research has been performed thanks to the economic support provided by DGAPA-

UNAM to Dr. Jimenez during her sabbatical year in South Africa.

\section{References}

Austin, A. (2001). Health aspects of ecological sanitation. Internet Dialogue on Ecological Sanitation. CSIR.

Austin, A. and Duncker, L. (2002). Urine-diversion Ecological Sanitation Systems in South Africa. CSIR, Pretoria.

Cabaret, J., Geerts, S., Madeline, M., Ballandonne, C. and Barbierc, D. (2002). The use of urban sewage sludge on pastures: the cysticercosis threat. INRA, EDP Sciences. Vet. Res., 33, 575-597.

Chale-Matsau, J.R.B. (2005). Persistence of human pathogens in a crop grown from sewage sludge treated soil. $\mathrm{PhD}$ thesis (Water utilization), Faculty of Engineering, University of Pretoria, Pretoria.

Esrey, S., Gough, J., Rapaport, D., Sawyer, R., Simpson-Hebert, M., Vargas, J. and Winblad, U. (1998). Ecological Sanitation. Sida, Stockholm.

Feachem, R., Bradley, J., Garelick, H. and Mara, D. (1983). Sanitation and Disease: Health Aspects of Excreta and Wastewater Management. John Wiley and Sons, Washington DC, USA.

Hazen, T. and Toranzos, G. (1990). Drinking Water Microbiology. G.A. McFeters Springer Verlag, $32-53$.

Heinonen-Tanski, H. and Van Wijk-Sijbesma, C. (2004). Human excreta for plant production. Biores. Technol., 96, 403-411.

Islam, M., Doyle, M.P., Phatak, S.C., Millner, P. and Jiang, X. (2005). Survival of Escherichia coli O157:H7 in soil and on carrots and onions grown in fields treated with contaminated manure composts or irrigation water. Food Microbiol., 22, 63-70.

Jiménez, B., Maya, C., Sánchez, E., Romero, A., Lira, L. and Barrios, J.A. (2002). Comparison of the quantity and quality of the microbiological content of sludge in countries with low and high content of pathogens. Wat. Sci. Technol., 46(10), 17-24.

Jimenez, B., Barrios, J., Mendez, J. and Diaz, J. (2004). Sustainable management of sludges in developing countries. Wat. Sci. Technol., 49(10), 251-258.

Jiménez, B. and Wang, L. (2006). Sludge treatment and management. In: Municipal Wastewater Management in Developing Countries, Ujang, Z. and Henze, M. (eds). IWAP, London.

Jiménez B., Maya C. and Schwartzbord, J. (2006). Comparison of techniques for the detection of helminth ova in wastewater. J. Wat. Environ. Res., 78(2), 118-124.

Jones, P. (1980). Health hazards associated with the handling of animal wastes. Vet. Rec., 106, 4-7.

Kudva, I., Blanch, K. and Hodve, C. (1998). Analysis of Escherichia coli O157:H7 survival in ovine and bovine manure and manure slurry. Appl. Environ. Microbiol., 64(9), 3166-3175.

Metcalf and Eddy, Inc. (2003). Wastewater Engineering: Treatment and Reuse, 4th edn, McGraw-Hill, USA.

Schonning, C. (2001). Hygienic aspects on the reuse of source-separated human urine. Wat. Environ. Microbiol., Swedish Institute for Infectious Disease control.

Standard Methods for the Examination of Water and Wastewater (1995). 19th edn, American Public Health Association/American Water Works Association/Water Environmental Federation, Washington DC, USA.

Strauss, M. (1994). Health implications of excreta and wastewater use. Hubei Environmental Sanitation Study. 2nd Workshop. Wuhan, China, March 3-4.

Strauss, M. and Blumenthal, U. (1990). Use of human wastes in agriculture and aquaculture. IRCWD Report No 08/90, Duebenforf, Switzerland.

Strauss, M., Drescher, S., Zurbrügg, C.H. and Montangero, A. (2003). Co-composting of faecal sludge and municipal organic waste. A literature and state-of-knowledge review. Swiss Federal Institute of Environmental Science \& Technology (EAWAG) and IMWI.

US EPA (1992). Environmental Regulation and Technology, Control of pathogens and vector attraction in sewage sludge, US EPA/625/R92/013 1992, Washington DC, USA. 152.

WHO Scientific Group (1989). Health guidelines for the use of wastewater in agriculture and aquaculture. Technical Report Series 778, World Health Organisation, Geneva.

W.R.C. (1997). Permissible utilization and disposal of sewage sludge. Water Research Commission TT, 85/97.

Xanthoulis, D. and Strauss, M. (1991). Reuse of wastewater in agriculture at Ouarzazate, Morocco. Project UNDP/FAO/WHO MOR 86/018. Unpublished mission reports. 